\title{
The Romanian Consumer Among Education, Information, Health Risk, Food Quality and Ethics
}

\author{
CEZARA VOICA ${ }^{1 *}$, CRISTINA ROSU ${ }^{2 *}$, ANDREEA MARIA IORDACHE ${ }^{3}$, IOANA CRISTINA PISTEA ${ }^{2}$, \\ MARIUS GHEORGHE MIRICIOIU** \\ ${ }^{1}$ National Institute for Research and Development of Isotopic and Molecular Technologies, 67-103 Donath Str., 400293, \\ Cluj-Napoca, Romania \\ ${ }^{2}$ Faculty of Environmental Science and Engineering, Babeş-Bolyai University, 30 Fantanele Str. 400294, Cluj-Napoca, \\ Romania \\ ${ }^{3}$ National Research and Development Institute for Cryogenics and Isotopic Technologies, 4 Uzinei Str., 240401, \\ Ramnicu-Vâlcea, Romania
}

\begin{abstract}
The food quality and the safety must be a constant concern both for consumers and for authorities. The education for quality and the active involvement, coherent and sustained by the state, through the implementation of a quality strategy at national level should be the main "forces" that can contribute to the implementation and certification of quality management systems in the agri-food sector. The meat and milk products are important components in the human diet; therefore, their contamination with heavy metals plays a significant role in the public health. The concentrations of several human essential trace elements $(\mathrm{Mn}, \mathrm{Cu}, \mathrm{Zn}$ and $\mathrm{Ba})$ and toxic elements $(\mathrm{As}, \mathrm{Cd}, \mathrm{Pb})$ were analysed in 95 animal-based foods, including meat, milk products and honey, collected from Romanian market. The inductively coupled plasma mass spectrometry technique (ICP-MS) was used for the determinations. In order to evaluate the potential health risk of the consumers due to metals intake via food ingestion, three indices were calculated, namely: the potential average daily dose $\left(A D D_{p o t}, m g / k g / d a y\right)$, the hazard quotient $(H Q)$ and the hazard index (HI). In terms of food safety, the toxic element concentrations in the majority of the investigated samples were below the maximum permitted levels set by Romanian and European legislation.
\end{abstract}

Keywords: food quality, trace elements, health risk, ICP-MS, legislation

Food is the basis of life and is the element from nature that provides the energy and vitality of the body, contributing to our well-being and health. Food security is a fundamental human right and can only be achieved through the availability of resources and their accessibility, through the use and sustainability of a healthy, sufficient, adequate and nutritious diet. Within the overall quality approach, as a strategic tool of industry global management, food products represent a very important place in EU policy. The qualitative requirements imposed for these products are due to the prospects of numerical growth of the consumers and, on the other hand, to the numerous and costly agrifood crises they have faced and which have jeopardised the confidence in the quality and safety of food products from EU. In this context, the European Union recommends the monitoring of food products starting from the obtaining stage of the raw materials and ending at the consumer. This strategy aims to protect and regain the consumer confidence from the Member States by adopting specifically legislative actions based primarily on the precautionary principle.

Food contamination is a public health problem around the world and the risk associated with the exposure to the trace metals, from food products, has aroused a widespread concern in human health [1]. Food safety is a major health concern, therefore, the assessment of heavy metals content in food products and their dietary intake are mandatory in order to evaluate the health risk. In food is a wide variety of essential trace elements, such as $\mathrm{Fe}, \mathrm{Mn}, \mathrm{Cu}, \mathrm{Zn}$, and Se, which are necessary in small amounts for living organisms, to assure the vital physiological and biochemical functions [2]. These elements can be toxic for humans if they are ingested in high concentrations [3]. The elements, such as $\mathrm{Pb}$, As, $\mathrm{Cd}, \mathrm{Hg}$, and $\mathrm{Sn}$, have no functional effects and they can be harmful for humans if are ingested. Animal products are in the forefront of the consumer and food industry interest, providing proteins, vitamins, and minerals to human organisms [4]. Various compounds, which contain $\mathrm{Fe}, \mathrm{Cu}, \mathrm{Zn}, \mathrm{Mn}$, or $\mathrm{Co}$, are allowed as feed ingredients for foodproducing animals $[5,6]$. Once ingested by animals, small fractions of these elements are absorbed, satisfying their nutritional needs. For example, a fraction of $10 \%$ or $20 \%$ of the ingested $\mathrm{Cu}$ and $\mathrm{Zn}$ is absorbed in the animal body [6]. The trace elements in animal products food (cheese, milk and meat) are variable due to some factors, such as: the

*email: cezara_voica@yahoo.com; cristina.rosu@ubbcluj.ro; marius.miricioiu@icsi.ro 
differences between species, the possible contamination of the storage and packaging equipment and the geographical area of animal husbandry. The dietary intake of chemical elements depends on their concentrations in food and also on the amount of food consumed. The essential elements are very important and necessary for the physiological functions of the human body and they should be available through dietary intake [7, 8].

Nowadays, Romania has become a major consumer market in the food sector, consequently, the Romanian consumer should learn how to identify the quality of food products through honest information and education.

The Romanian consumer faces three big dilemmas:

a) How natural/polluted is the food from the market?

b) How fast can be distinguish the quality of food by reading and understanding the information written on the labels?

c) How is the quality of Romanian food in comparison with the European one?

The general consumer concerns, regarding these realities and fears, are the effect of policies and strategies that project far above the information level and decision-making. The sufficient and correct knowledge of the main needs, the serious and honest information, the correlation of needs with possibilities, could be the solutions to the consumer questions.

Ethics is not always present in this field; the consumers are those who suffer from low quality products. Even with the implementation of the newest and safety food control systems, it is impossible to control everything. Chemical analyses constitute an important tool for quality control in the food industry and the precise determination of essential and toxic elements content in food is quite important, because there is a narrow margin of safety between adequate amount and overconsumption. The mineral and heavy metal contents in animal product food have been determined by many researchers, using different methods, such as atomic absorption spectrophotometry [9], flame atomic absorption spectrometry (F-AAS) [10, 11], inductively coupled plasma-atomic emission spectrometry (ICP-AES), inductively coupled plasma-mass spectrometry (ICP-MS) [12-14], inductively coupled plasma optical emission spectrometry (ICP-OES) [15].

The main objectives of the present study were $i$ ) the content analysis of several human essential trace elements $(\mathrm{Mn}, \mathrm{Cu}, \mathrm{Zn}, \mathrm{Ba}$ ) and toxic elements (As, $\mathrm{Cd}, \mathrm{Pb}$ ) in 95 animal-based food samples, including meat, milk, cheese and honey, produced in Romania and collected from the markets; ii) the evaluation of possible human health risk associated with the ingestion of these food products and iii) the comparison between Romanian and European legislations and the ethical issues identification.

\section{Experimental part}

Sample processing and analytical methods

A total of 95 different samples were collected from Romanian markets (local producers): pork and beef meat, ovine and cow products (cheese and milk) and honey (acacia, linden, canola and sunflower). Considering that the samples have very complex composition with large organic matter content, the total digestion of the matrix is mandatory, to assure a complete metal solubility. The samples were treated with microwave-assisted nitric acid, using a closed vessel speed wave system MWS-2 (Berghof, Germany). A Perkin Elmer ELAN DRC-e instrument (Waltham, Massachusetts, United States), equipped with a Meinhard nebulizer and a glass cyclonic spray chamber for pneumatic nebulization, was used for all elements measurements. The operating conditions were: gas flow in nebulizer - $0.92 \mathrm{~L}$. $\min ^{-1}$, auxiliary gas flow $-1.2 \mathrm{~L} \cdot \mathrm{min}^{-1}$, plasma gas flow $-15 \mathrm{~L} \cdot \mathrm{min}^{-1}$, lens voltage $-7.25 \mathrm{~V}$, radiofrequency power $1100 \mathrm{~W}, \mathrm{CeO} / \mathrm{Ce}$ ratio $=0.030$ and $\mathrm{Ba}^{++} / \mathrm{Ba}$ ratio $=0.026$.

\section{Health risk assessment}

This study was focused on the determination of six elements, some of them being toxic. Thus, manganese (Mn) is an essential nutrient for humans, being required in trace amounts to maintain cellular processes in human body, [16]. Cooper $(\mathrm{Cu})$ and zinc $(\mathrm{Zn})$ are very important for normal metabolism, growth and development [17]. Zn has greater bioavailability from meat than from vegetables. According to the Agency for Toxic Substances [18], $\mathrm{Cu}$ is an essential element for some biochemical processes in human body, but in high content in food could cause health problems. Also, barium $(\mathrm{Ba})$ has negative effects on human health, conducting to cardiovascular and kidney diseases and to neurological disorders.

Due to their toxicity, the elements, such as $\mathrm{As}, \mathrm{Cd}$ and $\mathrm{Pb}$ have the most negative impact on human health, inducing multiple organ damage, even at lower levels of exposure. According to the U.S. Environmental Protection Agency and to the International Agency for Research on Cancer these elements are classified as human carcinogens.

In order to evaluate the potential health risk of the consumers, due to the metal intake via food ingestion, there were calculated three indices: the potential average daily dose $\left(\mathrm{ADD}_{\mathrm{pot}}, \mathrm{mg} / \mathrm{kg} / \mathrm{day}\right)$, the hazard quotient (HQ) and the 
hazard index (HI). The resident exposure to the analysed metals was evaluated by calculating the potential average daily dose $\left(\mathrm{ADD}_{\mathrm{pot}}, \mathrm{mg} / \mathrm{kg} / \mathrm{day}\right)$, based on the US EPA model [19], using the equation (1). The non-carcinogenic risk was evaluated based on the hazard quotient (HQ), according to the equation (2), which represents the ratio between the average daily dose of a specific metal and its reference dose $\left(R_{f} D\right)$ [20]. In order to evaluate the possible health risk, due to exposure to multiple trace metals, the hazard index (HI) was calculated by summing the HQ of each metal $[6,20]$.

$$
A D D_{\text {pot }}=\frac{c_{\text {metaI }}-I R \cdot E D}{B W \cdot A T}
$$

where:

$\mathrm{C}_{\text {metal }}$ - the metal concentration in food product $(\mathrm{mg} / \mathrm{kg})$,

IR - the ingestion rate of chicken tissue per capita ( $\mathrm{kg} / \mathrm{day})$,

ED - the exposure duration (days),

BW - the body weight $(\mathrm{kg})$,

AT - the time period over which the dose is averaged (days).

$$
H Q=\frac{A D D}{R_{f} D}
$$

The HI and HQ values higher than 1 indicate a potential non-carcinogenic risk and lower than 1 confirm that the exposed population is safe [21].

\section{Ethical approach regarding the food safety}

European food safety policy takes into account the whole chain of food consumption by animals or humans. The national and international regulations, regarding the food quality, have lowered the maximum permissible levels of toxic metals in food. Romania had its own food safety legislation until 2009, where the maximum values for As, Cd, $\mathrm{Pb}, \mathrm{Zn}$ and $\mathrm{Cu}$ [22] were regulated and it was repealed by Order 176/2009 [23]. Nowadays, Romanian/European legislation has only a few maximum values, such as: $\mathrm{As}$ and $\mathrm{Zn}$ (for honey), $\mathrm{Cd}$ (for meat and honey) and $\mathrm{Pb}$ (for meat, milk and honey).

\section{Results and discussions}

In the table 1 are presented the element concentration in various food samples from different classes, namely: meat, milk, cheese and honey.

Table 1

ELEMENT CONCENTRATION IN VARIOUS FOOD SAMPLES

\begin{tabular}{|c|c|c|c|c|c|c|c|c|}
\hline Sample & \multicolumn{7}{|c|}{ Element $\left(\boldsymbol{\mu g} \cdot \mathbf{g}^{-\mathbf{1}}\right)$} \\
\hline & & Mn & $\mathbf{C u}$ & $\mathbf{Z n}$ & $\mathbf{B a}$ & $\mathbf{A s}$ & $\mathbf{C d}$ & $\mathbf{P b}$ \\
\hline & & 0.481 & 2.726 & 60.849 & 0.240 & 0.017 & 0.005 & 0.078 \\
pork meat & mean $(\mathrm{n}=12)$ & \pm 0.038 & \pm 0.188 & \pm 4.228 & \pm 0.015 & \pm 0.001 & \pm 0.0004 & \pm 0.002 \\
\hline & & 0.362 & 3.402 & 112.990 & 0.243 & 0.028 & 0.010 & 0.362 \\
beef meat & mean $(\mathrm{n}=5)$ & \pm 0.025 & \pm 0.297 & \pm 9.452 & \pm 0.015 & \pm 0.001 & \pm 0.001 & \pm 0.028 \\
\hline & & 0.595 & 2.572 & 30.144 & 0.894 & 0.095 & 0.008 & 0.024 \\
cow milk & mean $(\mathrm{n}=15)$ & \pm 0.044 & \pm 0.108 & \pm 2.781 & \pm 0.079 & \pm 0.003 & \pm 0.0007 & \pm 0.001 \\
\hline & & 0.775 & 2.432 & 23.788 & 1.260 & 0.089 & 0.023 & 0.045 \\
ovine milk & mean $(\mathrm{n}=10)$ & \pm 0.068 & \pm 0.113 & \pm 1.551 & \pm 0.099 & \pm 0.003 & \pm 0.001 & \pm 0.003 \\
\hline & & 0.626 & 2.535 & 73.855 & 1.626 & 0.119 & 0.005 & 0.038 \\
cow cheese & mean $(\mathrm{n}=19)$ & \pm 0.051 & \pm 0.135 & \pm 5.552 & \pm 0.146 & \pm 0.005 & \pm 0.0004 & \pm 0.002 \\
\hline & & 1.313 & 3.653 & 47.472 & 1.653 & 0.109 & 0.014 & 0.058 \\
ovine cheese & mean $(\mathrm{n}=10)$ & \pm 0.086 & \pm 0.211 & \pm 3.411 & \pm 0.144 & \pm 0.009 & \pm 0.001 & \pm 0.004 \\
\hline & & 0.238 & 0.339 & 0.876 & 0.137 & 0.003 & & 0.031 \\
acacia honey & mean $(\mathrm{n}=13)$ & \pm 0.012 & \pm 0.027 & \pm 0.077 & \pm 0.018 & \pm 0.0002 & $<0.001$ & \pm 0.002 \\
\hline & & 2.544 & 0.423 & 1.089 & 0.394 & 0.011 & & 0.049 \\
linden honey & mean $(\mathrm{n}=3)$ & \pm 0.109 & \pm 0.038 & \pm 0.085 & \pm 0.028 & \pm 0.001 & $<0.001$ & \pm 0.003 \\
\hline & & 0.380 & 0.305 & 5.963 & 0.138 & 0.009 & & 0.069 \\
canola honey & mean $(\mathrm{n}=3)$ & \pm 0.029 & \pm 0.0198 & \pm 0.335 & \pm 0.008 & \pm 0.0008 & $<0.001$ & \pm 0.005 \\
\hline
\end{tabular}


From table 1 it can be seen that the highest concentration was for $\mathrm{Zn}$ in beef sample, namely $112.990 \mu \mathrm{g} \cdot \mathrm{g}^{-1}$, while in the pork sample the $\mathrm{Zn}$ concentration decreased to $60.849 \mu \mathrm{g} \cdot \mathrm{g}^{-1}$. Similar value was reported in literature for $\mathrm{Zn}$ concentration in pork meat [13].

High $\mathrm{Zn}$ concentrations were also found in cow cheese and ovine cheese, 73.855 \pm 5.552 and 47.472 \pm 3.411 , respectively. It can be explained because the pasturage herbs are influenced by environmental conditions and can accumulate high concentrations of $\mathrm{Zn}$.

There were no significant differences between $\mathrm{Cu}$ contents in beef and pork meat, this being confirmed by others researchers $[24,25]$.

The $\mathrm{Pb}$ concentrations were higher in ovine products than in cow products, namely $0.045 \pm 0.003$ and $0.058 \pm 0.004$. The values are in accordance with the data presented in literature [26, 27]. Similar tendencies were observed for the $\mathrm{Mn}, \mathrm{Ba}$ and $\mathrm{Cd}$ contents.

The presence of $\mathrm{Pb}$ in dairy products may be due to environmental sources, such as atmospheric deposition and urban effluent, but in the case of $\mathrm{Cd}$, it can be due to the natural or anthropogenic origins. The presence of toxic metals in milk and dairy products can be a result of environmental conditions and manufacturing process.

The contents of analysed elements in honey samples increased as follow $\mathrm{Cd}<\mathrm{As}<\mathrm{Pb}<\mathrm{Ba}<\mathrm{Cu}<\mathrm{Mn}<\mathrm{Zn}$. The maximum concentration of $\mathrm{Zn}$ was found in canola honeys $\left(17.888 \mu \mathrm{g} \cdot \mathrm{g}^{-1}\right)$. A source of $\mathrm{Zn}$ contamination can be the galvanized containers used for honey storing. The linden honey has higher levels of Mn $\left(2.544 \pm 0.109 \mu \mathrm{g} \cdot \mathrm{g}^{-1}\right), \mathrm{Ba}$ $\left(0.394 \pm 0.028 \mu \mathrm{g} \cdot \mathrm{g}^{-1}\right)$ and As $\left(0.011 \pm 0.001 \mu \mathrm{g} \cdot \mathrm{g}^{-1}\right)$ than acacia and canola honey.

The content ranges of elements in honey and in meat samples are shown in figure 1.
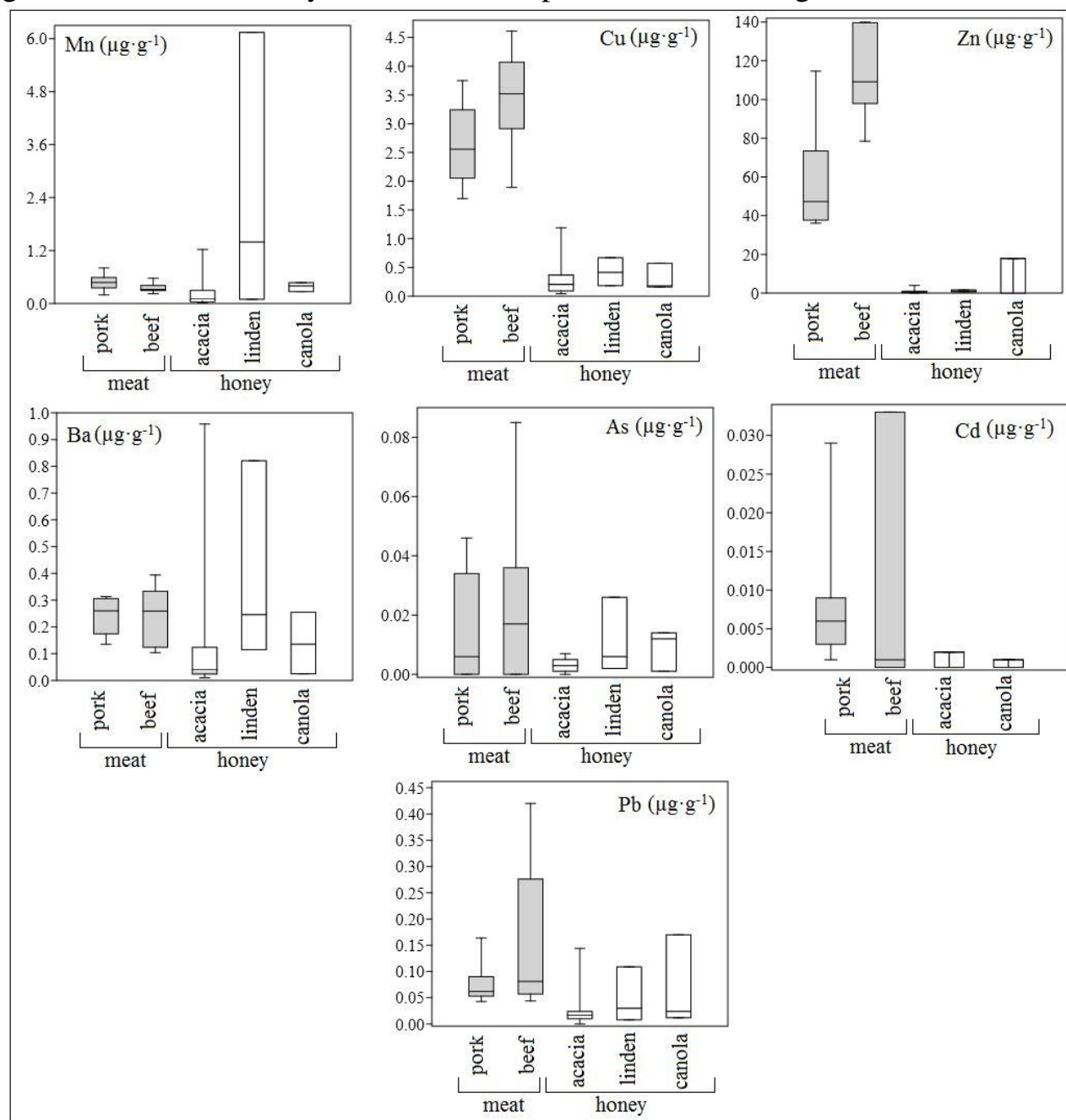

Fig. 1. The concentration of essential trace elements $(\mathrm{Mn}, \mathrm{Cu}, \mathrm{Zn}$ and $\mathrm{Ba})$ and toxic elements

$(\mathrm{As}, \mathrm{Cd} \mathrm{Pb})$ in meat and honey samples

Comparing the results from figure 1, it can be noticed that the highest values obtained for $\mathrm{Cu}, \mathrm{Zn}$, As and $\mathrm{Cd}$ were lower in honey than in meat samples. 
In table 2 are presented the concentration of elements in studied samples and the standard limits. Comparing these data, it can be observed $i$ ) that the honey is the best regulated food product regarding the metal domain; ii) there are no exceedings of the legislative values for all 4 categories of analysed foods (meat, milk, cheese and honey); iii) the $\mathrm{Cu}$, $\mathrm{Mn}$ and $\mathrm{Ba}$ are not legislated.

Table 2

CONCENTRATION OF ELEMENTS IN STUDIED SAMPLES (MEAN \pm STANDARD DEVIATION, $\left.\mu \mathrm{G} \cdot \mathrm{G}^{-1}\right)$ IN COMPARATION WITH STANDARD LIMITS

\begin{tabular}{|c|c|c|c|c|c|c|c|c|}
\hline Sample & $\begin{array}{c}\text { Number } \\
\text { of } \\
\text { samples }\end{array}$ & $\mathbf{M n}$ & $\mathbf{C u}$ & $\mathbf{Z n}$ & $\mathbf{B a}$ & As & $\mathbf{C d}$ & $\mathbf{P b}$ \\
\hline Meat & 17 & $\begin{array}{c}0.444 \\
\pm 0035\end{array}$ & $\begin{array}{c}2.925 \\
\pm 0.178\end{array}$ & $\begin{array}{c}74.476 \\
\pm 5.118\end{array}$ & $\begin{array}{c}0.243 \\
\pm 0.014\end{array}$ & $\begin{array}{c}0.019 \\
\pm 0.001\end{array}$ & $\begin{array}{c}0.006 \\
\pm 0.0005\end{array}$ & $\begin{array}{c}0.103 \\
\pm 0.007\end{array}$ \\
\hline Legislation & & $\mathrm{NS}$ & $\mathrm{NS}$ & $\mathrm{NS}$ & $\mathrm{NS}$ & $\mathrm{NS}$ & $0.05^{1,3}$ & $0.1^{1,2,3}$ \\
\hline Milk & 25 & $\begin{array}{c}0.725 \\
\pm 0.065\end{array}$ & $\begin{array}{c}2.717 \\
\pm 0.166\end{array}$ & $\begin{array}{c}29.103 \\
\pm 1.890\end{array}$ & $\begin{array}{c}1.036 \\
\pm 0.080\end{array}$ & $\begin{array}{c}0.090 \\
\pm 0.008\end{array}$ & $\begin{array}{c}0.014 \\
\pm 0.001\end{array}$ & $\begin{array}{c}0.035 \\
\pm 0.002\end{array}$ \\
\hline Legislation & & $\mathrm{NS}$ & $\mathrm{NS}$ & $\mathrm{NS}$ & $\mathrm{NS}$ & $\mathrm{NS}$ & $\mathrm{NS}$ & $0.02^{1.2,3}$ \\
\hline Cheese & 33 & $\begin{array}{c}1.165 \\
\pm 0.098\end{array}$ & $\begin{array}{c}2.966 \\
\pm 0.159\end{array}$ & $\begin{array}{c}62.067 \\
\pm 4.220\end{array}$ & $\begin{array}{c}1.711 \\
\pm 0.120\end{array}$ & $\begin{array}{c}0.151 \\
\pm 0.012\end{array}$ & $\begin{array}{c}0.009 \\
\pm 0.0007\end{array}$ & $\begin{array}{c}0.046 \\
\pm 0.002\end{array}$ \\
\hline Legislation & & $\mathrm{NS}$ & $\mathrm{NS}$ & $\mathrm{NS}$ & $\mathrm{NS}$ & $\mathrm{NS}$ & $\mathrm{NS}$ & $\mathrm{NS}$ \\
\hline Honey & 20 & $\begin{array}{c}0.606 \\
\pm 0.054\end{array}$ & $\begin{array}{c}0.327 \\
\pm 0.020\end{array}$ & $\begin{array}{c}1.717 \\
\pm 0.108\end{array}$ & $\begin{array}{c}0.169 \\
\pm 0.015\end{array}$ & $\begin{array}{c}0.005 \\
\pm 0.0004\end{array}$ & $\begin{array}{c}0.001 \\
0.038 \\
\pm 0.002\end{array}$ \\
\hline Legislation & & $\mathrm{NS}$ & $\mathrm{NS}$ & $20^{3}$ & $\mathrm{NS}$ & $0.2^{3}$ & $0.03^{3}$ & $0.3^{4}$ \\
\hline
\end{tabular}

\footnotetext{
NS-unspecified

${ }^{1}$ European legislation [28], ${ }^{2}$ European legislation [8], ${ }^{3}$ Romanian legislation [29],

${ }^{4}$ European legislation [30]
}

Analysing the values from table 2, it can be seen that the lowest European legislation limits are for $\mathrm{Cd}\left(0.05 \mu \mathrm{g} \cdot \mathrm{g}^{-1}\right)$ and $\mathrm{Pb}\left(0.02 \mu \mathrm{g} \cdot \mathrm{g}^{-1}\right)$ in meat and milk, repsectively, these meaning that are very dangerous for human body, due to their toxicity.

The potential average daily dose $\left(\mathrm{ADD}_{\mathrm{pot}}, \mu \mathrm{g} / \mathrm{kg} / \mathrm{day}\right)$, caused by the ingestion of essential trace elements $(\mathrm{Mn}, \mathrm{Cu}$, $\mathrm{Zn}, \mathrm{Ba})$ and toxic elements $(\mathrm{As}, \mathrm{Cd}, \mathrm{Pb}$ ) from food, is presented in figure 2 . 
Fig. 3. The hazard quotient (HQ) for each metal and the hazard index $(\mathrm{HI})$

Fig. 2. Potential average daily dose ( $\left.A D D_{\text {pot }}, \mu \mathrm{g} / \mathrm{kg} / \mathrm{day}\right)$, caused by the ingestion of essential trace elements $(\mathrm{Mn}, \mathrm{Cu}, \mathrm{Zn}$ and $\mathrm{Ba})$ and toxic elements $(\mathrm{As}, \mathrm{Cd}, \mathrm{Pb})$ in the analysed samples

The results indicated that the $\mathrm{ADD}_{\text {pot }}$ values were considerably lower in the case of milk and honey due to the lower level of metals and lower ingestion ratio for these food products. The meat consumption lead to the ingestion of higher contents of essential trace elements, like $\mathrm{Cu}$ and $\mathrm{Zn}$, while the cheese consumption increases the content of $\mathrm{Ba}$. The $\mathrm{ADD}_{\text {pot }}$ for $\mathrm{Pb}$ and $\mathrm{Cd}$ were higher for meat ingestion, while the $\mathrm{ADD}_{\text {pot }}$ for $\mathrm{As}$ was higher for cheese ingestion.

Based on the $\mathrm{ADD}_{\text {pot }}$ values, the hazard quotient (HQ) was calculated for each metal, in order to evaluate the noncarcinogenic risk of residents, due to metals uptake via food ingestion. The results are presented in figure 3.

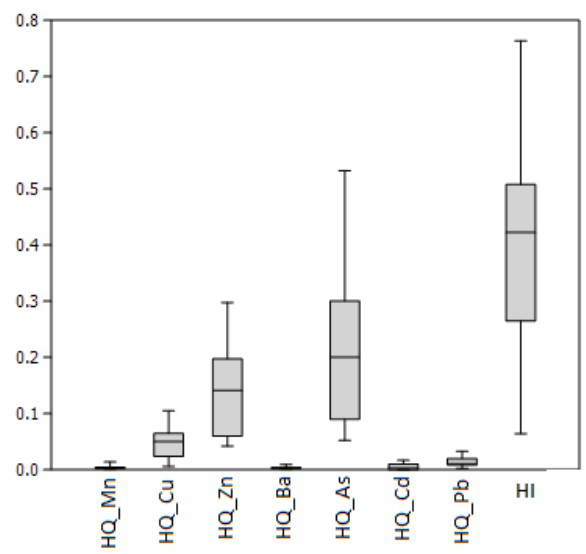

The data revealed that the $\mathrm{Mn}, \mathrm{Ba}, \mathrm{Cd}$ and $\mathrm{Pb}$ ingestion had a lower non-carcinogenic risk due to their low $\mathrm{HQ}$ intervals values, namely: 0.0009-0.0139 for $\mathrm{Mn}, 0.0013-0.0093$ for $\mathrm{Ba}, 0.0002-0.0128$ for $\mathrm{Cd}$ and $0.0025-0.0330$ for $\mathrm{Pb}$. The HQ level was higher for As (0.0523-0.5322), $\mathrm{Zn}(0.0420-0.2978)$ and $\mathrm{Cu}(0.0059-0.1052)$.

In order to evaluate the possible health risk caused by the exposure to multiple trace metals, the hazard index (HI) was calculated by summing the HQ values. The HI ranged between 0.06 and 0.764 (figure 3), being lower than 1 in all 
cases and indicating that the resident exposure to metals from consumption of dairy products, meat and honey did not pose any significant non-carcinogenic risk.

The HQ values of the metals for adult decreased in the order $\mathrm{As}>\mathrm{Zn}>\mathrm{Cu}>\mathrm{Pb}>\mathrm{Cd}>\mathrm{Mn}>\mathrm{Ba}$, as it is shown in figure 4.

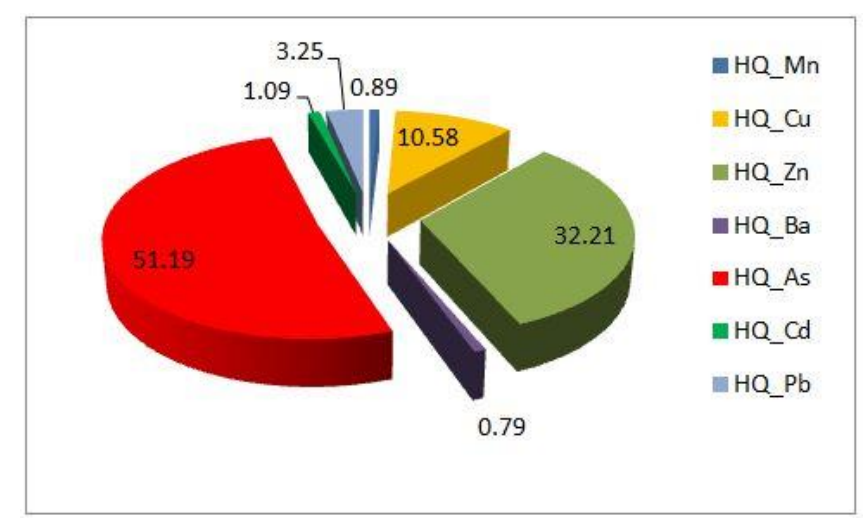

The As was the most dangerous metal among the studied elements, with a high risk for human, contributing with approximately half of the total HQ.

\section{Conclusions}

Four essential elements $(\mathrm{Mn}, \mathrm{Cu}, \mathrm{Zn}$ and $\mathrm{Ba}$ ) and three toxic metals ( $\mathrm{As}, \mathrm{Cd}, \mathrm{Pb}$ ) were determined by ICP-MS, after microwave digestion, in four classes of food products (meat, milk, cheese and honey).

The obtained results indicated some significant differences between elements content in the studied classes of food.

a) No major problems have been identified regarding the toxic metal contamination of the analysed samples. The concentrations of $\mathrm{As}, \mathrm{Cd}$ and $\mathrm{Pb}$ in all samples were below the maximum limits allowed in the International and National food safety Standards.

b) The presence of $\mathrm{Zn}$ and $\mathrm{Cu}$ in meat, cheese and milk products can be considered a good thing because their deficiency in the body can lead to serious illnesses.

Generally, beef meat and cow cheese presented higher contents of Zn, these being better sources of the essential element than other products, from the nutritional point of view.

c) The low concentrations of toxic metals, such as $\mathrm{Cd}, \mathrm{As}$, and $\mathrm{Pb}$, in the analysed honey samples, confirm their quality.

d) In order to evaluate the potential health risk of the consumers caused metal intake via food ingestion, three indices were calculated: the potential daily dose, the hazard quotient and the hazard index. The highest HQ contribution was given by As (51.19\%), followed by $\mathrm{Zn}(32.21 \%)$ and by $(10.58 \%)$.

$\begin{array}{ll}\begin{array}{ll}\text { Fig. 4. Contribution of } \\ \text { each metal HQ to the } \\ \text { total HQ for adult }\end{array} & \begin{array}{l}\text { by average } \\ \text { Cu }\end{array}\end{array}$

and

Acknowledgements: The financial support for this work was provided by the Ministry of Research Innovation, Programs Nucleu, contract no. PN 18030202 and contract no. PN 19350202.

\section{References}

1. KAMALA, K., KUMAR, V.P. Chapter 1 - Food Products and Food Contamination. Microbial Contamination and Food Degradation. A volume in Handbook of Food Bioengineering, 2018, p. 1, doi.org/10.1016/B978-0-12-811515-2.00001-9.

2. NECUlA, R., GILlE, E., DIRTU, A.C., SANDU, I., GRADINARU, V.R., PETCU, A., DROCHIOIU, G., Rev. Chim., 69, no. 7, 2018, p. $1682-1686$.

3. CAC (CODEX Alimentarius Commission), General Standard for Contaminants and Toxins in Food and Feed (CODEX STAN 193-1995, Amended in 2016). Joint FAO/WHO Food Standards Programme, Geneva, Switzerland, 2016.

4.*** MOA (Ministry of Agriculture), Lists of Additives Permitted to Use in Animal Feeds, Announcement No. 2045 of the Ministry of Agriculture, Beijing, China, 2013.

5. SIMITZIS, P.E., DELIGEORGIS, S.G., Food Quality: Balancing Health and Disease. A volume in Handbook of Food Bioengineering. Chapter 8 - Agroindustrial By-Products and Animal Products: A Great Alternative for Improving Food-Quality Characteristics and Preserving Human Health, 2018, p. 253.

6.HU, Y., ZHANG, W., CHEN, G., CHENG, H., TAO, S., Environ. Pollut., 234, 2018, p. 667, doi.org/10.1016/j.envpol.2017.12.006 
7.DJINOVIC-STOJANOVIC, J.M., NIKOLIC D.M., VRANIC, D.V., BABIC, J.A., MILIJASEVIC, M.P., PEZO, L.L., JANKOVIC, S.D., J. Food. Compos. Anal., 59, 2017, p. 50.

8.*** FAO/WHO food standards program: Codex committee on contaminants in foods (Editorial amendments to the general standard for contaminants and toxins in food and feed), sixth session, Maastricht, Netherlands, 2012; CX/CF 12/6/11. http://www.fao.org/tempref /codex/Meetings/CCCF/CCCF6/cf06_11e.pdf

9. ALQARNI, A.S., OWAYSS, A.A., MAHMOUD, A.A., HANNAN, M.A., J. Saudi Chem. Soc., 18, 2014, p. 618.

10. BILANDŽIĆ, N., SEDAK, M., ĐOKIĆ, M., BOŽIĆ, D., KOLANOVIĆ, B.S., VARENINA, I., Mljekarstvo, 64, no. 3, 2014 , p.150.

11. BILANDZIC, N., GACIC, M., DOKIC, M., SEDAK, M., SIPUSIC, D.I., KONCURAT, A., GAJGER I.T., J. Food Compos. Anal., 33, 2014, p. 132.

12. DANEZIS, G.P., PAPPAS, A.C., ZOIDIS, E.G., HADJIGEORGIOU, I., ZHANG, P., BRUSIC, V., GEORGIOU, C.A., Anal. Chim. Acta, 991, 2017, p. 46.

13. BATISTA, B.L., GROTTO, D., CARNEIRO, M.F.H., BARBOSA, J.F., J. Toxicol. Env. Heal. A, 75, no. 21, 2012 , p. 1269.

14. GEORGESCU, A.A., DANET, A.F., RADULESCU, C., STIHI, C., DULAMA, I.D., BURULEANU, C.L., Rev. Chim., 68, no. 10, 2017, p. 2402 .

15. BASERI, E., ALIMOHAMMADI, M., NODEHI, R.N., NAZMARA, S., KHANIKI G.J., ES'HAGHI GORJI, M., Iranian Journal of Health, Safety and Environment, 5, no. 1, 2018, p. 926.

16. ZIPKIN, F.B., FALCIGLIA, G.A., KUHNELL, P. \& HAYNES, E.N., International Journal of Environmental Research and Public Health, 14, 1060, 2017, p. 2.

17. KHAN, N., JEONG, I.S., HWANG, I.M., KIM, J.S., CHOI, S.H., NHO, E.Y., CHOI, J.Y., PARK, K.S., KIM, K.S., Food Chem., 147, $2014,220$.

18.*** Agency for toxic substances and Disease registry, Department of Health and Human Services. Public Health Statement for Copper, 2005.

19.*** USEPA Unites States Environmental Protection Agency, Guidelines for Exposure Assessment. Federal Register 57, 104, 1992 , p. 22888.

20.*** USEPA, Unites States Environmental Protection Agency, Reference Dose (RfD): Description and use in Health Risk Assessments, Background Document 1A, 1993 https://www.epa.gov/iris/reference-dose-rfd-description-and-usehealth-risk-assessments.

21. WANG, R., ZHONG, B., PI, L., XIE, F., CHEN, M., DING, S., SU, S., LI, Z., GAN, Z., Archives on Environmental Contamination and Toxicology, 74, 2018, 131. https://doi.org/10.1007/s00244-017-0420-y.

22.*** Order No. 975 of 16 December 1998 on the approval of the Sanitary and Sanitary Norms for Food, Order of the Minister of Health, Official Monitoring no. 268, 1999.

23.*** Order No. 176 of 18 February 2009 for repealing the Order of the Minister of Health no. 975/1998 on the approval of the sanitarysanitary norms for food, Order of the Minister of Health, Official Monitoring no. 114, 2009.

24. TOMOVIC, V., PETROVIC, L.J., TOMOVIC, M., KEVRESAN, Z., DZINIC, N., Food Chem., 124, 2011, p. 342.

25.LOPEZ-ALONSO, M., MIRANDA, M., CASTILlO, C., HERNANDEZ, J., GARCIA VAQUERO, M., BENEDITO, J.L., Food Addit. Contam., 24, no. 9, 2007, p. 943.

26. ANASTASIO, A., CAGGiAnO, R., MACChiAtO, M., PAOlO, M., PAINO, S., CORTESI, M.L., Acta Vet. Scand., 47, 2006, p. 69.

27. AYAR, A., SERT, D., AKM, N., Environ. Monit. Assess., 152, 2009, p. 1.

28.*** European Commission Regulation No 1881/2006, the Framework EU Legislation Which Sets Maximum Levels for Chemical Contaminants in Foodstuffs, 2006.

29.*** Order No. 1201/106 of 22 December 2003 on the completion of the Order of the Minister of Health and Family and of the Minister of Agriculture, Food and Forests no. 84/91/2002 for the approval of the Norms on contaminants in food, Official Monitoring, 17, no. $142,2004$.

30.*** Codex Alimentarius Commission, Revised Codex Standard for Honey, Codex STAN adopted in 1981, revisions 1987 and 2001

$\overline{\text { Manuscript received: } 11.07 .2019}$ 